
ОРИГИНАЛЬНЫЕ СТАТЬИ

\title{
THE WINTER DIET OF THE RARE TYTO ALBA IN CONTRAST TO ASIO OTUS ON CRIMEA PENINSULA
}

\author{
Volodymyr M. Kucherenko ${ }^{1, *}$, Nikolay N. Tovpinets ${ }^{2}$, \\ Angelina V. Slavinskaya ${ }^{1}$, Sergey N. Yakunin ${ }^{3}$, Irina S. Kovalenko ${ }^{3}$ \\ ${ }^{1}$ V.I. Vernadsky Crimean Federal University, Crimea \\ ${ }^{2}$ Centre of Hygiene and Epidemiology in Crimea and in the Municipal City Sevastopol, Crimea \\ ${ }^{3}$ Plague Control Station in the Republic of Crimea, Crimea \\ *e-mail: zookuch@ukr.net
}

Received: 04.12.2019. Revised: 17.03.2020. Accepted: 28.04.2020.

\begin{abstract}
The range of Tyto alba overlaps with that of Asio otus in a large part of the Holarctic. Both species are adapted to open-area hunting and prey upon similar species. In contrast to A. otus, data about the diet of T. alba on Crimea and surroundings are extremely scarce. Our study aimed to describe the prey spectrum of T. alba and evaluate at what extant its diet overlaps to that of $A$. otus. We evaluated diets based on 48 pellets of T. alba and 88 of A. otus collected from January to March 2018 in the Western part of the Crimea Peninsula. Simultaneously, we assessed the availability of small mammal prey by installing 150 spring-loaded bar mousetraps around the collection sites. Small mammals were the main prey in the diet of T. alba and A. otus (99.2\% and $100 \%$ of all individuals in pellets). The most consumed species of both species was Microtus socialis (52.3\% and $74.4 \%$ of all individuals). The second most consumed species of T. alba was Crocidura leucodon, an endangered species in Crimea. The diet of $T$. alba was more diverse than that of $A$. otus (Shannon diversity Index: 1.1 and 0.76 , Simpson Index: 0.51 and 0.31 , respectively). However, their diets overlapped widely (Pianka's index $=0.94$ ). The frequency of mammalian prey in traps correlated moderately with that in $A$. otus pellets $\left(r_{s}=0.5, p<0.2\right)$, and it deviated from the frequency of mammalian prey in T. alba pellets $\left(\mathrm{r}_{\mathrm{s}}=-0.05, \mathrm{p}<0.9\right)$. The presence of the endangered C. leucodon in the diet of T. alba reinforce the utility of this predator species as a tool to detect threatened or rare small mammals that are not caught by traps and to increase information about their geographical distribution.
\end{abstract}

Key words: Aves, Bicoloured shrew, diet diversity, dietary overlap, Social vole, Strigiformes

\section{Introduction}

Tyto alba (Scopoli, 1769) is a widespread polytypic species. It breeds in South, Central and North America, Africa, except the Sahara, Mediterranean, South Asia, Australia and islands. In Europe, it occupies territories from the Atlantic coast to western Latvia, Belarus in the north and to the Black sea coast in the south (Zubkov, 2005; Bashta \& Bokotey, 2009). In Ukraine, it is a rare species with a breeding population estimated in 30 pairs, most of which are in West Ukraine (Bashta \& Bokotey, 2009). Some authors have also observed breeding pairs and single individuals in the Pre-Caucasian region of the Russia Federation (Zubkov, 2005; Ilyukh \& Khokhlov, 2010). On the Crimea Peninsula, a few migrating and wintering individuals and breeding pairs have been registered in the XXI century (Prokopenko \& Beskaravayny, 2009; Kucherenko et al., 2017).
The range of $T$. alba is overlapped to that Asio otus (Linnaeus, 1758) in a large part of the Holarctic (Leader et al., 2010). Both species have a nocturnal and crepuscular activity, and they are adapted to open-area hunting and prey upon similar animals. However, they also have some ecological differences. Asio otus breeds in forest remnants in the vicinity of open landscapes or in the forest belts among arable fields, locating nests in trees, where it uses old nests of Corvidae, and hunting both from perches and in flight. In winter, individuals of $A$. otus form communal roosts. Tyto alba breeds in farmland with scattered copes and locates nests in natural (e.g., tree holes) or artificial (e.g., nest boxes, barns) cavities. In winter, individuals of T. alba tend to roost alone. Understanding how top predators are trophically related is essential to establish prey-based conservation strategies. 
Some recent studies provide detailed information about the ecology of A. otus on Crimea, primarily on the characteristic of winter roosts and on the trophic relationships (Tovpinets \& Evstaf'ev, 2013; Kucherenko \& Kalinovsky, 2018). In contrast, information about the trophic ecology of T. alba on Crimea and surroundings is scarce (e.g. Koshelev \& Belashkov, 2002; Prokopenko \& Beskaravayny, 2009; Ilyukh \& Khokhlov, 2010). This is due to the rarity of this species in the area, which is the reason why this species is in the Red Data Book of the Republic of Crimea (Beskaravayny, 2015).

Our study aimed to describe the prey spectrum of $T$. alba and evaluate at what extant its diet overlaps to that of $A$. otus in an area where they are sympatric in Crimea Peninsula. Moreover, as we found an endangered Crocidura species among the prey of T. alba, we noted the utility of T. alba pellets for detecting threatened small mammals.

\section{Material and Methods}

We conducted our research in the Western part of the Crimea Peninsula, an area with open cultivated and uncultivated agricultural land. We collected 48 pellets of T. alba in ruined buildings in Saky district $\left(45.327957^{\circ} \mathrm{N}, 33.064789^{\circ} \mathrm{E}\right)$ on 12.02.2018 and 14.03.2018 (Fig. 1). On this site, we only observed a single wintering individual of $T$. alba, which perched inside the building. We collected all pellets under this perch. We collected 88 pellets of $A$. otus on 25.01.2018 on a site where owls formed a communal roost. It is located a few kilometres northeast from the wintering site of $T$. alba. Since the pellets of $T$. alba and A. otus (Fig. 2) differ considerably in size, we had no doubt about which species the pellets were of.

We analysed only entire pellets (i.e., no broken ends, no fragmentation, no splitting or loosening of pellets), teasing them apart by dry manual dissection (Holt et al., 1987). The pellets only contained remains of mammals and birds. We identified mammalian prey species by comparing the mandibles, craniums (whole or broken) and tibias recovered from pellets with our own bone collection of local mammals, and according to Gromov (1995). In the case of avian prey, we compared feather fragments, large bones (e.g., tarsus) and beaks with plates in field guides (Fesenko \& Bokotey, 2002; Svensson, 2010) and with bird skins maintained in the Zoological Museum of V.I. Vernadsky Crimean Federal University. We determined the number of individuals in each pellet by counting the number of the most frequent body element (e.g., number of left or right mandibles or tibiae, number of beaks or presence of feathers) (YomTov \& Wool, 1997). If we could not categorically distinguish the body pieces of congeneric species, we combined them within the same genus. To assess the consumed biomass we used literature data about prey weight (Panteleev et al., 1990; Fesenko \& Bokotey, 2002; Ronald \& Walker, 2005; Kryštufek \& Vohralik, 2009).

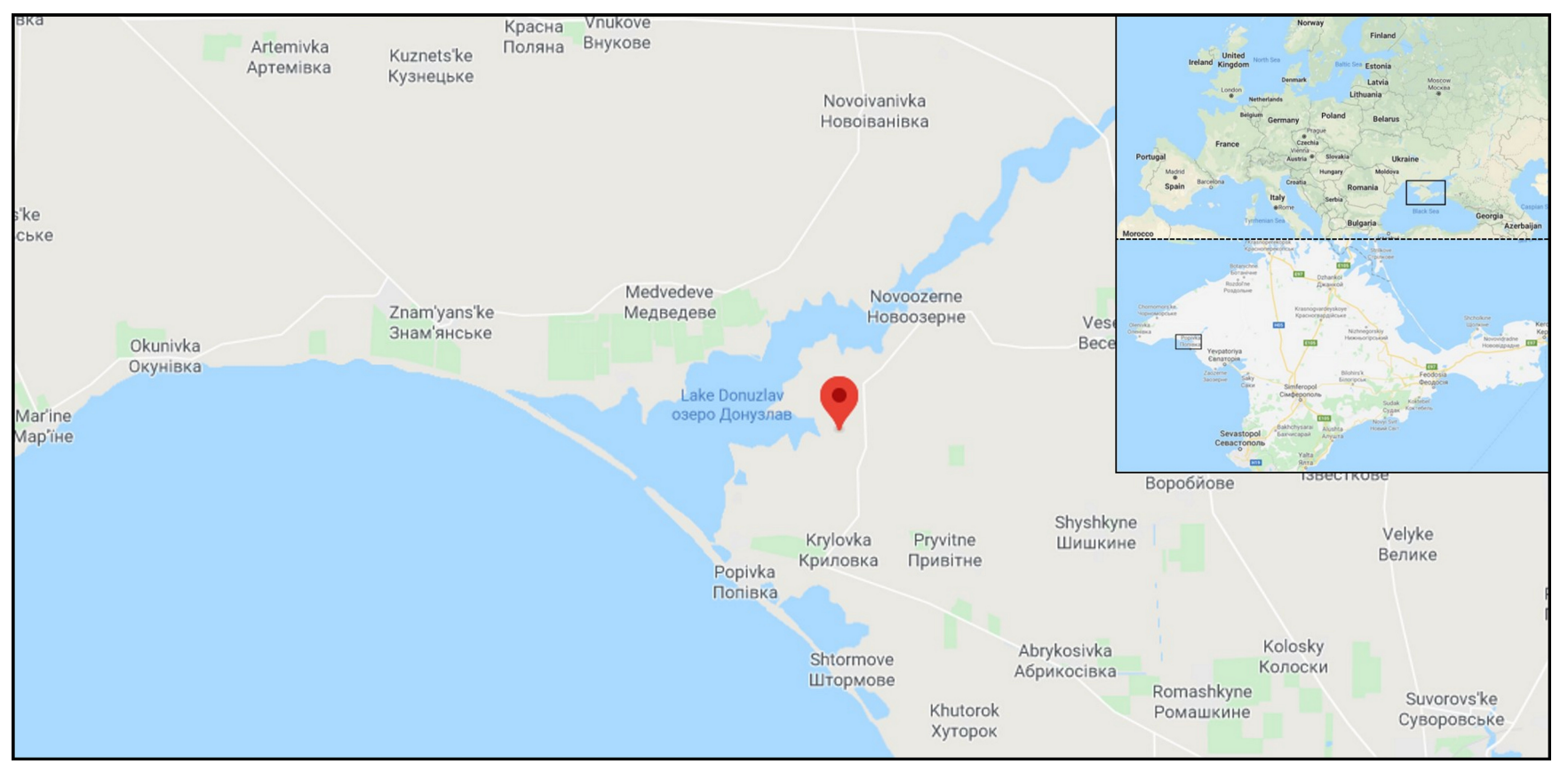

Fig. 1. Study area of the winter diet of Tyto alba and Asio otus on the Crimea Peninsula. Red dot - both species' pellet collection site. 

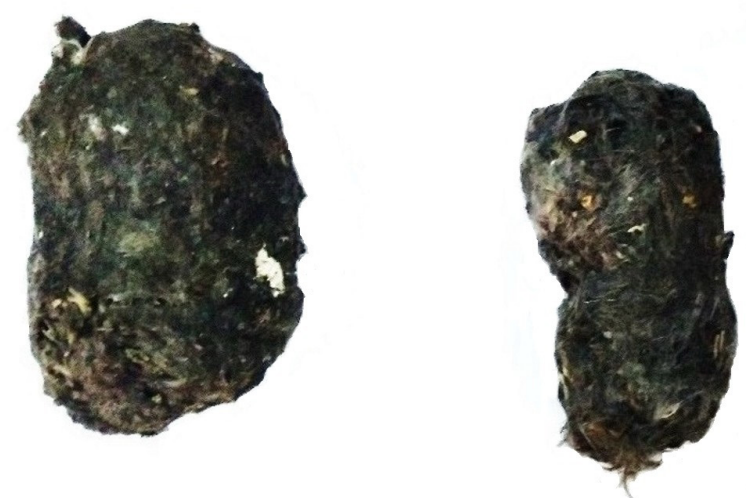

\section{$\begin{array}{lllllllllll} & 1 & 2 & 3 & 4 & 5 & 10 & 11 & 12 & 13 & 14\end{array}$}

Fig. 2. Pellets of Tyto alba (left) and Asio otus (right) collected during winter 2018 in the western part of the Crimea Peninsula.

We measured the size of the pellets of both owl species. It can be useful for identifying both species (at the local level) if only their pellets are found. To estimate the differences in the mean number of individuals per pellet and biomass per pellet between $T$. alba and $A$. otus, we used the $t$-Student test and visual comparison. We used $\chi^{2}$ to detect differences between the frequencies of the most important genus in pellets of both species.

We also compared the diets of T. alba and $A$. otus by estimating two food niche metrics: diet diversity (food breadth) and dietary overlap. We estimated the food diversity of the prey species level by using the antilog of the Shannon index and the Simpson index, as they display the foodniche breadth (Pesenko, 1982; Magurran, 2004). To standardise food diversity for comparison between $T$. alba and A. otus, we also calculated food evenness (Alatalo, 1981). To contrast indexes of food diversity, we used the $t$-Student test. We measured the dietary overlap as follow:

$$
O_{x y}=\frac{\sum P_{i x} \times \sum P_{i y}}{\sqrt{\sum P_{i x}^{2} \times \sum P_{i y}^{2}}},
$$

where $O_{x y}$ - Pianka's measure of niche overlap between species $x$ and species $y ; P_{i x}$ - Proportion resource $i$ is of the total resources used by species $x ; P_{i y}$ - Proportion resource $i$ is of the total resources used by species $y$.

To evaluate whether owls consume small mammal prey according to its field availability, we compared the frequency in pellets versus the frequency in field by trapping small mammals. We used two data sources to obtain an approximation to the small mammal availability in the field. First, we derived the field availability of small mammals around the study area from a long-term study on the small mammal fauna in Crimea conducted between 1986 and 2016 (Evstafiev, 2016). To obtain a more refined approximation of the field abundance of small mammals, we conducted small mammal trappings in our study site simultaneously to the pellet collection by using spring-loaded bar mousetraps. On 14-15 March 2018, we established three 50-traps transect-lines across the most typical biotopes (total effort $=150$ trap-night). To attract the mammals, we used bread with sunflower oil. We calculated the overall frequency of small mammal species by summing all individuals captured in each transect-line. Since the number of small mammals captured by trapping and the number of prey in pellets refers to relative counts, we used the prey/ pellets ratio and prey/traps ratio for comparison. Thus, to infer a congruency between consumption and availability of prey species, we contrast the number of individuals per pellets versus the number of individuals captured per traps (non-functional traps discounted) by using the Spearman correlation $\left(r_{s}\right)$. We conducted all statistical calculations by using PAST software (Hammer et al., 2001).

\section{Results}

The pellets of T. alba contained 258 individuals belonging to at least eight species (Table 1). We could not categorically assign 20 individuals to either Mus musculus Linnaeus, 1758, or Mus spicilegus Petenyi, 1882, while possibly T. alba preyed upon M. musculus too. We combined them into the M. musculus/spicilegus complex. The most frequent species in pellets was Microtus socialis (Pallas, 1773) reaching about half of all individuals, followed by Crocidura leucodon (Hermann, 1780) and M. spicilegus (Table 1). The remaining species accounted for about $1 \%$ of all individuals. Among the mammalian prey, we also identified a single individual of Mustela nivalis Linnaeus, 1766. Turdus merula Linnaeus 1758 was the only avian prey identified in pellets of T. alba.

Although the number of collected pellets of $A$. otus was almost twice as that of T. alba, they contained fewer prey individuals and less species (Table 1). The most frequent species in pellets of A. otus was Microtus socialis. The remaining species individually accounted for less than $10 \%$ of all individuals each. The proportions of biomass of consumed species were very similar to their species ratio in the diet (Table 2). 
Table 1. Prey species in pellets of Tyto alba $(\mathrm{n}=48)$ and Asio otus $(\mathrm{n}=88)$ during the winter 2018 on the Crimea Peninsula and the frequency of small mammals in the field as estimated by live-trapping

\begin{tabular}{|l|c|c|c|c|c|c|}
\hline \multirow{2}{*}{ Prey } & \multicolumn{2}{c|}{ Tyto alba } & \multicolumn{2}{c|}{ Asio otus } & \multicolumn{2}{c|}{ trapping } \\
\cline { 2 - 7 } & Number & Proportion, \% & Number & Proportion, \% & Number & Proportion, \% \\
\hline Microtus socialis (Pallas, 1773) & 135 & 52.3 & 166 & 74.4 & 5 & 31.3 \\
\hline Sylvaemus witherbyi (Thomas, 1902) & 4 & 1.6 & 7 & 3.1 & - & - \\
\hline Mus musculus Linnaeus, 1758 & - & - & 10 & 4.5 & 8 & 50.0 \\
\hline Mus specilegus Petenyi, 1882 & 16 & 6.2 & 6 & 2.7 & - & - \\
\hline Mus musculus/spicilegus & 20 & 7.8 & 20 & 9.0 & - & - \\
\hline Cricetulus migratorius (Pallas, 1773) & 1 & 0.4 & 10 & 4.5 & - & - \\
\hline Crocidura suaveolens (Pallas, 1811) & 12 & 4.7 & 4 & 1.8 & 3 & 18.7 \\
\hline Crocidura leucodon (Hermann, 1780) & 30 & 11.6 & - & - & - & - \\
\hline Crocidura suaveolens / leucodon & 38 & 14.7 & - & - & - & - \\
\hline Mustela nivalis Linnaeus, 1766 & 1 & 0.4 & - & - & - & - \\
\hline Turdus merula Linnaeus 1758 & 1 & 0.4 & - & - & - & - \\
\hline Total & 258 & 100 & 223 & 100 & 16 & - \\
\hline
\end{tabular}

Table 2. The biomass, consumed by Tyto alba and Asio otus during the winter 2018 on the Crimea Peninsula (48 and 88 pellets respectively)

\begin{tabular}{|l|c|c|c|c|c|}
\hline \multirow{2}{*}{ Prey } & \multirow{2}{*}{ Mass, g } & \multicolumn{2}{c|}{ Tyto alba } & \multicolumn{2}{c|}{ Asio otus } \\
\cline { 3 - 6 } & & Biomass & Proportion, \% & Biomass & Proportion, $\%$ \\
\hline Microtus socialis & 23 & 3105 & 66.0 & 3818 & 76.4 \\
\hline Sylvaemus witherbyi & 27 & 108 & 2.3 & 189 & 3.8 \\
\hline Mus musculus & 16 & - & - & 160 & 3.2 \\
\hline Mus specilegus & 16 & 256 & 5.4 & 96 & 2.0 \\
\hline Mus musculus/spicilegus & 16 & 320 & 6.8 & 320 & 6.4 \\
\hline Cricetulus migratorius & 38 & 38 & 0.8 & 380 & 7.6 \\
\hline Crocidura suaveolens & 8 & 96 & 2.0 & 32 & 0.6 \\
\hline Crocidura leucodon & 8 & 240 & 5.1 & - & - \\
\hline Crocidura suaveolens/leucodon & 8 & 304 & 6.5 & - & - \\
\hline Mustela nivalis & 140 & 140 & 3.0 & & - \\
\hline Turdus merula & 95 & 95 & 2.0 & & - \\
\hline Total & & 4702 & 100 & & - \\
\hline
\end{tabular}

Tyto alba produced greater pellets $(50.6 \pm 3.1$ mm length and $28.1 \pm 0.7 \mathrm{~mm}$ width, $\mathrm{n}=24)$ than $A$. otus (47 $\pm 1.6 \mathrm{~mm}$ length and $18.6 \pm 0.4 \mathrm{~mm}$ width, $\mathrm{n}$ $=20$ ) (Fig. 2). The length differences were not significant, but the width differed considerably ( $t$-Student test, $t=13.8, p<0.05)$. The mean number of individuals per pellet differed considerably between both species (Fig. 3): $5.4 \pm 0.3$ individuals per pellets for $T$. alba $(\mathrm{n}=48$ pellets) versus $2.3 \pm 0.1$ prey per pellets for $A$. otus ( $\mathrm{n}=88$ pellets; $t$-Student test, $t=11.6, p$ $<0.001)$. The mean biomass per pellet also differed considerably (Fig. 3): $97.7 \pm 5.1 \mathrm{~g}$ per pellet, for $T$. alba $(\mathrm{n}=48$ pellets $)$ versus $53.1 \pm 2.2 \mathrm{~g}$ per pellet for A. otus ( $t$-Student test, $t=9.2, p<0.001$ ).

The proportion of the most consumed mammalian prey at genus level (Microtus, Sylvaemus, Mus and Crocidura) differed significantly $\left(\chi_{3}^{2}=69.6\right.$, $p<0.001)$ between the pellets of T. alba and A. otus.

Tyto alba showed a more diverse diet that $A$. otus (Shannon index: 1.1 vs. 0.76; Simpson index: 0.51 vs. 0.31 ; evenness: 0.37 vs. 0.36 , respectively). Dif- ferences in diet diversity were statistically significant: Shannon index, $t$-Student test $t=2.8(\mathrm{df}=401.25$, $p<0.05)$; Simpson index, $t$-Student test $t=-3.3$, (df $=$ $399.8, p<0.01)$. There was a high similarity between the diets of $A$. otus and T. alba (Pianka's index =0.94).

The frequency of mammalian prey in traps correlated moderately with the frequency of mammalian prey in $A$. otus pellets $\left(r_{s}=0.5, p<0.2\right)$ (Fig. 4). The frequency of mammalian prey in traps deviated from the frequency of mammalian prey in the $T$. alba pellets $\left(r_{s}=-0.05, p<0.9\right)$.

\section{Discussion}

On the study site, small mammals were the primary prey of $T$. alba and A. otus during winter reaching $100.0 \%$ and $99.2 \%$ of all individuals identified in pellets, respectively. Microtus socialis formed almost three-quarters and almost half of the individuals consumed by $A$. otus and T. alba, respectively. According to literature data, rodents of the genus Microtus predominate in the diet of both species in Poland and 
Romania (Kitowsky, 2013; Petrovici et al., 2013), Greece (Alivizatos, 1999), and USA (Khalafalla \& Iudica, 2010). Possibly, the high consumption of those rodents is due to its higher abundance in the field in many places (e.g., Gromov, 1995; Volkov et al., 2009), increasing the probability that owls find them more often. However, throughout the long-term trapping of small mammals in the steppe on Crimea, the frequency of $M$. socialis was low, reaching only $6.8 \%$ of all small mammals captured (Evstafiev, 2016). Moreover, in our catches in the study area, $M$. socialis accounted for only one-third of the captured rodents. Such results agree with the suggestion that owl pellets do not accurately represent the proportion of prey species in the field (Yom-Tov \& Wool, 1997). On the other hand, it is also possible that trapping based on both live traps and spring-loaded bar mousetraps might not truly reflect the actual availability of small mammals in the field because that species could differently respond to them. We also have to admit that our trapping effort was overly low to obtain a robust ranking of field abundance of small mammal species. An alternative explanation for the high consumption of $M$. socialis by owls is that possibly this species is much more nocturnal than other rodent species, and so coinciding more fully with the circadian rhythm of T. alba and A. otus.
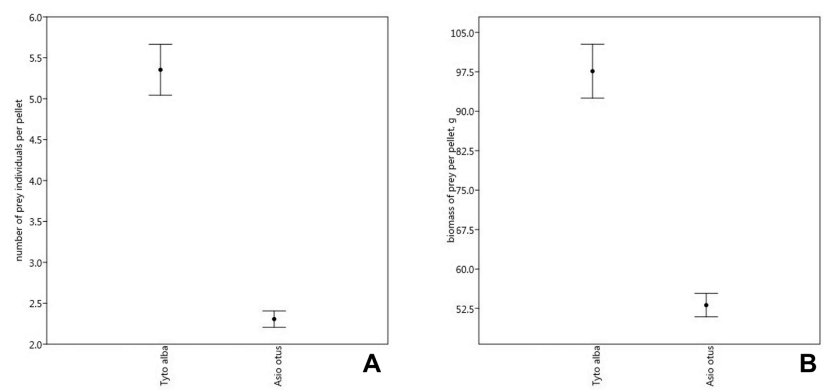

Fig. 3. Prey/pellets (A) and biomass/pellets (B) ratio for Tyto alba $(\mathrm{n}=48$ pellets $)$ and Asio otus ( $\mathrm{n}=88$ pellets) during the winter 2018 on the western Crimea Peninsula (dots - mean, «whiskers»-standard errors).

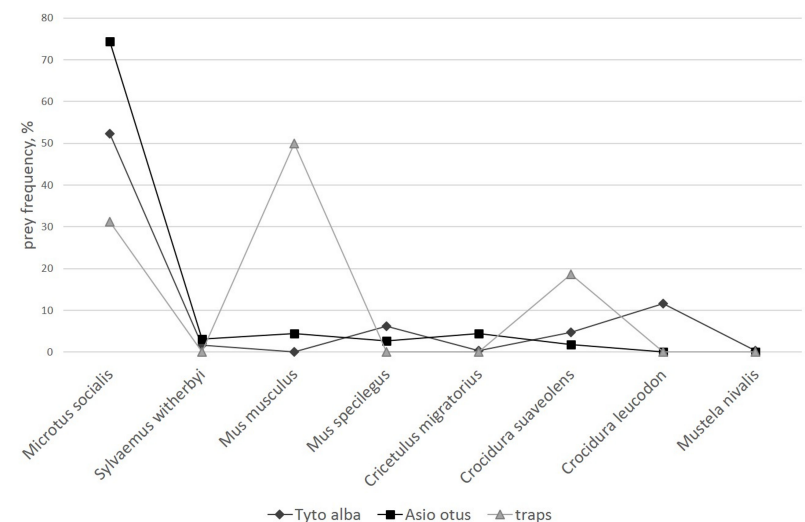

Fig. 4. The frequency of mammal prey species in pellets of Tyto alba and Asio otus and in the traps during the winter 2018 on the western Crimea Peninsula.
According to our results, T. alba preys on a broader range of animals than $A$. otus, and $T$. alba pellets contain a higher number of individuals and biomass compared to A. otus. Other authors noted a similar pattern in some other parts of their range (Khalafalla \& Iudica, 2010; Petrovici et al., 2013). However, we could not categorically determinate, if $T$. alba preys on Mus musculus as their bones were not easily distinguishable from those of M. specilegus. Although $A$. otus preys upon M. musculus on our study site, the representation in the pellet was low ( $<5 \%$ of all prey individuals). In a previous study (Tovpinets \& Evstaf'ev, 2013), we found that $M$. musculus was the primary prey species of $A$. otus in the steppe of the Crimea $(24.3 \%$ of all prey individuals), while Cricetulus migratorius was less common (6.2\%). Such regional variations in diet could be due to difference in prey availability.

Crocidura leucodon was the second most numerous prey (11.6\%) on the diet of T. alba. On the Crimea Peninsula, C. leucodon is an endangered species (Tovpinets, 2015). By regular trapping, conducted during 36 years (1980-2016) in the steppe zone of the Crimea Peninsula, Evstafiev (2016) could capture only 30 individuals of $C$. leucodon. For this reason, it is remarkable that $T$. alba had consumed 30 individuals of $C$. leucodon on our study site. Possibly, this species increases in number during winter within the hunting areas of T. alba. Moreover, C. leucodon prefers open habitats (Tovpinets, 2015), especially steppes, which make them more vulnerable for predation. It is noteworthy that $A$. otus had not consumed $C$. leucodon, as it is within the size range of their prey. Possibly, A. otus was unable to detect $C$. leucodon in the field, or it hunted on areas where that animal was absent.

The presence of an endangered shrew in the pellets of T. alba in our study site reinforce the utility of this owl species as tool to detect threatened or rare small mammals that are not caught by traps and to increase information about their geographical distribution (Avery at al., 2005). Our finding represents the most north-western record of Crocidura leucodon on the Crimea. On the other hand, the high proportion of one rare prey species in the diet of rare T. alba indicates the vulnerability of the ecosystem of the steppe on the Crimea because of the high probability that the loss of one rare species will negatively affect other rare species. On the Crimea, C. leu- 
codon inhabits the least cultivated steppe areas. So its low abundance can be an indicator of the destruction of the steppe areas.

Overall, the proportion of shrews in the diet of T. alba was much higher than in the diet of A. otus. Tyto alba consumed 80 individuals of two Crocidura species accounting for almost a third of all consumed prey. In contrast, $A$. otus preyed upon only four individuals of Crocidura suaveolens (Pallas, 1811) accounting for only $2 \%$ of the total number of prey. A higher proportion of Crocidura in the diet of T. alba compared with A. otus was also noted in Poland (Kitowsky, 2013), and Greece (Alivizatos, 1999).

Our analysis suggests that T. alba and A. otus have a very similar winter diet on the Crimean Peninsula. In different areas of their range, both species overlap widely in diet. In Pennsylvania (USA), the dietary overlap coefficient was 0.99 (Khalafalla \& Iudica, 2010), while in Eastern Poland 0.832 (Khalafalla \& Iudica, 2010; Kitowsky, 2013) and Romania 0.87 (Petrovici et al., 2013). This demonstrates that, in sympatry, $T$. alba and $A$. otus tend to converge toward the same spectrum of prey. Variation in consumption of some prey species could be a result of difference in habitat use or prey-handling ability.

The number of prey species per owl pellet differed from the number of prey species per trap, both from the trapping at a regional (Evstafiev, 2016) and local scale. At a regional scale, Sylvaemus witherbyi (Thomas, 1902) was the most captured species accounting for $45.4 \%$ of all trapped mammals. However, it was only accounted for $1.6 \%$ and $3.1 \%$ of all prey individual in pellets of T. alba and A. otus pellets, respectively. Mus musculus reached $33.2 \%$ of all captured mammals, but it was absent in pellets of T. alba and accounted for less than $5 \%$ of all prey in pellets of A. otus. In contrast, Microtus socialis, the most consumed rodent species by owls, accounted for only $6.8 \%$ of all trapped mammals. The captures of shrews were rare in the trappings and their proportion was low in the pellets of $A$. otus. However, shrews accounted for almost a third of all consumed prey by T. alba.

At a local scale, we captured three small mammal species in traps, with Mus musculus being the most frequent species, followed by Sylvaemus witherbyi and Crocidura suaveolens (Table 1). The fact that the proportion of species in traps notoriously differed with the ratio in pel- lets suggests that both T. alba and A. otus preyed differentially upon small mammals during winter in the study area. However, the small number of pellets and low trapping effort were insufficient to conclude prey selection robustly. Differences in diet diversity between $T$. alba and $A$. otus species could be associated to differences in hunting range, prey-handling ability or capture efficiency. On other parts of their range, these species also differ in diet diversity. In Israel and USA, the diet diversity of $A$. otus was higher than that of T. alba (Leader et al., 2010). On the contrary, in East Poland, T. alba showed a more diverse diet than A. otus (Kitowsky, 2013).

\section{Conclusions}

On the Crimea Peninsula, the winter diet of T. alba and A. otus composed mainly of small mammals, but with some difference in the importance level of prey species. The high dietary overlap between both owl species suggest that they converge on the same prey species within their hunting range. Differential predation on small mammals by $T$. alba and A. otus suggest they could select their prey species. But this requires confirmation. The presence of the endangered C. leucodon in the diet of T. alba reinforces the utility of this owl species as a tool to detect threatened or rare small mammals that are not caught by traps and to increase information about their geographical distribution.

\section{Acknowledgements}

We are indebted to S.P. Prokopenko, T.A. Zherebtsova and D. Yu. Zherebtsov for their help in the fieldwork. We thank the anonymous reviewers for their comments on an earlier version of the manuscript.

\section{References}

Alatalo R.V. 1981. Problems in the measurements of evenness in ecology. Oikos 37(2): 199-204. DOI: $10.2307 / 3544465$

Alivizatos H. 1999. Winter diet of the Barn Owl (Tyto alba) and Long-Eared Owl (Asio otus) in Northeastern Greece: a comparison. Journal of Raptor Research 33(2): 160-163.

Avery D.M.,Avery G., Palmer N.G. 2005. Micromammalian distribution and abundance in the Western Cape Province, South Africa, as evidenced by Barn owls Tyto alba (Scopoli). Journal of Natural History 39(22): 2047-2071. DOI: 10.1080/00222930500044631

Bashta A.T.V., Bokotey A.A. 2009. Barn Owl Tyto alba (Scopoli, 1769). In: I.I. Akimov (Eds.): Red Data 
Book of Ukraine. Animals. Kyiv: Globalconsalting. P. 470. [In Ukrainian]

Beskaravayny M.M. 2015. Tyto alba (Scopoli, 1769). In: S.P. Ivanov, A.V. Fateryga (Eds.): Red Data Book of the Republic of Crimea. Simferopol: IT ARIAL. P. 354. [In Russian]

Evstafiev I.L. 2016. Results of a 30-Years-Long Investigation of Small Mammals in Crimea. Part 2. Ecology of Species. Proceedings of the Theriological School 14: 103-120. DOI: 10.15407/ptt2016.14.103 [In Russian]

Fesenko G.V., Bokotey A.A. 2002. Birds of the fauna of Ukraine (field guide). Kyiv: Ukrainian society of bird protection. 416 p. [In Ukrainian]

Gromov I.M. 1995. Rodentia. In: The mammals of Russia and adjacent territory. St. Petersburg: Russian Academy of Science. P. 58-501. [In Russian]

Hammer Ø., Harper D.A.T., Ryan P.D. 2001. PAST: Paleontological Statistics Software Package for Education and Data Analysis. Palaeontologia Electronica 4(1): 1-9.

Holt D.W., Lyon J.L., Hale R. 1987. Techniques for differentiating pellets of Short-eared Owls and Northern Harriers. The Condor 89: 929-931.

Ilyukh M.P., Khokhlov A.N. 2010. Birds of Prey and Owls of transformed ecosystems of the Caucasus. Stavropol: SevCauGTU. 760 p. [In Russian]

Khalafalla S.M., Iudica C.A. 2010. Barn and Long-Eared Owl Diets: A Comparative Study from Central Pennsylvannia and a Key for Identification of Prey Items. Northeastern Naturalist 17(1): 147-154. DOI: 10.1656/045.017.0112

Kitowsky I. 2013. Winter diet of the Barn Owl (Tyto alba) and the Long-eared Owl (Asio otus) in Eastern Poland. North-Western Journal of Zoology 9(1): 16-22.

Koshelev A.I., Belashkov I.D. 2002. The first flight of Barn Owl (Tyto alba alba) into Melitopol region in winter 2002. Branta: Transactions of the Azov-Black Sea Ornithological Station 5: 146-149. [In Russian]

Kryštufek B., Vohralik V. 2009. Mammals of Turkey and Cyprus. Rodentia II: Cricetinae, Muridae, Spalacidae, Calomyscidae, Capromyidae, Hystricidae, Castoridae. Slovenia, Koper: University of Primorska. 372 p.

Kucherenko V.M., Prokopenko S.P., Zherebtsova T.A., Zherebtsov D.Yu. 2017. Observations of rare bird species in the Crimea in 2013-2017. Berkut 26(1): 1-4. [In Ukrainian]

Kucherenko V., Kalinovsky P. 2018. Winter Roost Tree Selection and Phenology of the Long-Eared Owl (Asio otus) in Crimea. Diversity 10(4): 105. DOI: $10.3390 / \mathrm{d} 10040105$
Leader Z., Yom-Tov Y., Motro U. 2010. Diet comparison between two sympatric Owls - Tyto alba and Asio otus - in the Negev Desert, Israel. Israel Journal of Ecology and Evolution 56(2): 207-216. DOI: 10.1560/IJEE.56.2.207

Magurran A.E. 2004. Measuring Biological Diversity. UK: Blackwell Publishing. 256 p.

Panteleev P.A., Terekhina A.N., Varshavsky A.A. 1990. Ecogeographic variation in rodents. Moscow: Nauka. 374 p. [In Russian]

Petrovici M., Molnar P., Sándor A.D. 2013. Trophic niche overlap of two sympatric owl species (Asio otus Linnaeus, 1758 and Tyto alba Scopoli, 1769) in the North-Western part of Romania. North-Western Journal of Zoology 9(2): 250-256.

Pesenko Yu.A. 1982. Principles and Methods of Quantities Analyses in Faunistic Research. Moscow: Nauka. 287 p. [In Russian]

Prokopenko S.P., Beskaravayny M.M. 2009. New data about distribution of the Barn Owl Tyto alba (Scop.): Tytonidae, Strigiformes in the Crimea. Branta: Transactions of the Azov-Black Sea Ornithological Station 12: 167-169. [In Russian]

Ronald M.N., Walker E.P. 2005. Walker's carnivores of the world. Baltimore and London: JHU Press. 313 p.

Svensson L. 2010. Collins Bird Guide. $2^{\text {nd }}$ edition. Italy: Trento. 448 p.

Tovpinets N.N. 2015. Crocidura leucodon Hermann, 1870. In: S.P. Ivanov, A.V. Fateryga (Eds.): Red Data Book of the Republic of Crimea. Simferopol: IT ARIAL. P. 367. [In Russian]

Tovpinets N.N., Evstaf'ev I.L. 2013. Small mammals in the winter diet of Long-eared Owl (Asio otus) from the Crimea: ecological and epizootological aspects. Berkut 22(2): 113-121. [In Russian]

Volkov S.V., Sharikov A.V., Basova V.B., Grinchenko O.S. 2009. Influence of small mammals abundance on the number and selection of habitats by Longeared (Asio otus) and Short-eared (Asio flammeus) Owls. Zoologicheskii Zhurnal 88(10): 1248-1257. [In Russian]

Zubkov N.I. 2005. Barn Owl Tyto alba (Scopoli, 1769). In: V.T. Butyev, N.I. Zubkov, V.P. Ivanchev (Eds.): Birds of Russia and adjacent regions: Strigiformes, Caprimulgiformes, Apodiformes, Coraciiformes, Upupiformes, Piciformes. Moscow: KMK Scientific Press Ltd. P. 99-106. [In Russian]

Yom-Tov Y., Wool D. 1997. Do the contents of Barn Owl pellets accurately represent the proportion of prey species in the field? The Condor 99: 972-976. 


\title{
ЗИМНЕЕ ПИТАНИЕ РЕДКОГО ВИДА ТУТО $A L B A$ В СРАВНЕНИИ С ASIO OTUS В КРЫМУ
}

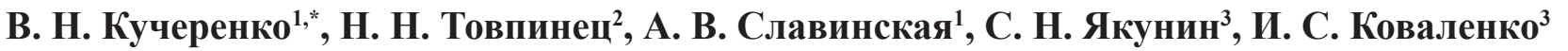 \\ ${ }^{1}$ Крымский федеральный университет имени В.И. Вернадского, Крым

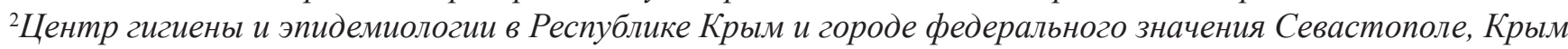 \\ ${ }^{3}$ Противочумная станция Республики Крым, Крым \\ *e-mail: zookuch@ukr.net
}

Ареал распространения Tyto alba перекрывается с ареалом Asio otus на значительной части Палеарктики. Оба вида приспособлены к охоте на открытой местности и выбирают схожую добычу. Данные о $T$. alba в Крыму и на прилегающей территории крайне скудны, в то время как A. otus является обычным видом. Целью нашего исследования было описание спектра добычи T. alba и сравнение степени перекрывания трофической ниши с $A$. otus. Мы оценили рационы на основе содержимого 48 погадок T. alba и 88 погадок A. otus, собранных с января по март 2018 года в западной части Крымского полуострова. Одновременно мы оценили доступность добычи мелких млекопитающих, установив 150 пружинных мышеловок в районе места сбора погадок. Останки млекопитающих содержали 99.2\% погадок T. alba и $100 \%$ погадок A. otus. Наиболее потребляемой добычей обоих видов была Microtus socialis (52.3\% и 74.4\% всех жертв). Субдоминантом в погадках T. alba была Crocidura leucodon - редкий вид крымской фауны. Диета T. alba была более разнообразной, чем диета A. otus (индекс разнообразия Шеннона: 1.1 и 0.76, индекс Симпсона: 0.51 и 0.31, соответственно). Тем не менее, их диеты широко перекрываются (индекс Пианки $=0.94)$. Доля видов добычи в погадках не коррелировала с их соотношением в ловушках. Наличие находящихся под угрозой исчезновения Crocidura leucodon в рационе T. alba показывает большое значение этого вида в качестве инструмента обнаружения находящихся под угрозой или редких мелких млекопитающих, которые не попадают в мышеловки и для увеличения информации об их географическом распространении.

Ключевые слова: Aves, Strigiiformes, белобрюхая белозубка, общественная полевка, перекрывание трофической ниши, спектр питания 